\title{
Culture, Science, and Activism in Florida Lawn and Landscape Fertilizer Policy
}

\author{
Christopher D. Ryan ${ }^{1}$, J. Bryan Unruh ${ }^{1}$, Kevin E. Kenworthy ${ }^{2}$, \\ Alexa J. Lamm ${ }^{3}$, John E. Erickson ${ }^{2}$, and Laurie E. Trenholm ${ }^{1}$
}

ADDITIONAL INDEX WORDs. turfgrass, decision maker, discourse analysis, eutrophication, Foucault, survey

\begin{abstract}
SUMMARY. Every county and municipality in Florida can adopt its own unique ordinance regulating the fertilization of lawns and landscapes. With increased concern for eutrophication to state waterbodies, many have chosen to implement seasonal fertilizer restrictive periods prohibiting the application of nitrogen and phosphorus fertilizers, typically during the rainy summer months. These fertilizer "blackout" policies have been the subject of controversy among environmental activists, university scientists, and policy decision makers, with their efficacy being called into question. A Foucauldian discourse analysis was undertaken to trace the dynamics of the controversy, and survey research was conducted with Florida residents and with Florida decision makers to compare their lawncare maintenance practices, sentiments surrounding turfgrass, their trust in landscape science, as well as their awareness of policy in the city or county in which they reside. Differences were found between the two populations in terms of how many respondents fertilized, used automated irrigation systems and hand-pulled weeds. Although both populations had very neutral sentiments around turfgrass with no significant differences, Florida decision-maker respondents had a higher mean response for trust in landscape science. Only $32 \%$ of Florida resident respondents were able to accurately identify if their city or county had a blackout ordinance, compared with $81 \%$ of decision-maker respondents. Increasing civic science may be the best way for reducing this discrepancy, while also giving power to citizens in environmental policy adoption.
\end{abstract}

$\mathrm{T}$ The symbolic power of the lawn is substantial. Although a person's home and neighborhood are a "public portrait of themselves" (Nassauer, 1995), the lawn is not merely an individualistic endeavor and is subject to communal-social and regulatory forces. For example, many municipalities have ordinances specifying irrigation restrictions, prohibition of nuisance weeds, or grass height limits, although these ordinances are usually enforced only by

$\overline{\text { Received for publication } 11 \text { Apr. 2019. Accepted for }}$ publication 29 July 2019.

Published online 5 November 2019.

${ }^{1}$ University of Florida, 1549 Fifield Hall, P.O. Box 110670, Gainesville, FL 32611

${ }^{2}$ University of Florida, 3105 McCarty B, Gainesville, FL 32611

${ }^{3}$ University of Florida, 305 Rolfs Hall, P.O. Box 110540, Gainesville, FL 32611

We thank the participants of these two surveys. Gratitude is also extended to the University of Florida/Institute for Food and Agricultural Science Center for Public Issues Education for Agriculture and Natural Resources for both funding and assistance in this research.

C.D.R. is the corresponding author. E-mail: cryan@ ufl.edu.

This is an open access article distributed under the CC BY-NC-ND license (https://creativecommons.org/ licenses/by-nc-nd/4.0/).

https://doi.org/10.21273/HORTTECH04283-19 neighbor complaint (Sisser et al., 2016). Foucault (1978) outlines an approach useful in locating "the forms of power, the channels it takes, and the discourse it permeates in order to reach $[\ldots]$ individual modes of behavior," a larger process involving what he terms "the polymorphous techniques of power." This Foucauldian analysis of discourse emphasizes the power relations that "shape the physical world," emphasizing not only the textual representations of discourse, but also actions, practices, and events (Sharp and Richardson, 2001). In the Foucauldian sense, competing discourses represent struggles for legitimacy, and structural changes in society are relative to the dominance of a particular discourse with implication to the adoption of policy. The truth of an argument is less of a consideration, but rather focus is placed on "how, why, and by who" truth is established (Sharp and Richardson, 2001).

This method of discourse analysis relies on identifying key components of a phenomenon. First, one must identify sites of discursive production, including where silences are administered. Focus must be placed on the individuals who are speaking, along with the institutions that are behind these individuals, as well as the positions these individuals and institutions take. Second, one must locate where power is produced. Systems and individuals involved in this power production must take key interest. This power production is not only in the form of legal regulation, but takes form in spoken (marketing, extension, media) and unspoken social pressures (values and norms). Third, one must analyze sites of knowledge propagation, as these are the areas in which notions begin to circulate, regardless of validity. These sites most obviously include institutions of research, but extend to include any group or individual who acts as a source of information or authority regarding landscape practices (Foucault, 1978).

Homeowner's associations (HOAs) and building codes can dictate percentages of turfgrass coverage, forcing homeowners to use the necessary environmental resources to achieve these mandated guidelines (Souto and Marshall, 2007). Some HOAs are responsible for hiring lawncare services for their entire neighborhood, truly unifying their neighborhood under a single standard (Downs, 2007). In some cases, HOA regulations might be directly at odds with legal guidelines for landscaping practices and water use. As expressed by a resident in a Florida focus group, HOAs would fine residents for not keeping their lawn at a certain aesthetic standard, particularly during drought conditions, resulting in homeowners illegally watering their lawn and then facing fines from law enforcement instead (Downs et al., 2012).

The power that the law yields must not be understated. In 2011, a woman in Oak Park, MI, faced 93 $\mathrm{d}$ in jail for refusing to remove a vegetable garden from her front yard after converting from a turfgrass landscape (Hoffer, 2011). A similar case surfaced in 2016 in Miami Shores, FL, when a neighbor complaint prompted a front-yard vegetable garden of 17 years to become a site of legal conflict. Facing fines of $\$ 50$ per day, the owners filed a lawsuit against the city in response (Ovalle, 2016). Although these cases may represent more extreme examples, they do 
demonstrate the potential for lawn aesthetics to be legally enforced.

The discourse and political atmosphere over personal lawns can be divided into two groups: those who question current lawn practices and those who aim to keep the status quo of a lawn aesthetic. These two groups find themselves at polarized ends of a larger landscape discourse, and ironically both groups highlight similar themes of purity and pollution in relation to the lawn. Antilawn sentiment is tied with notions of naturalization and regional identity, whereas prolawn sentiment supports lawns as "marker[s] of community" (Feagan and Ripmeester, 2001). Those who question the status quo of the turfgrass lawn as a landscape aesthetic often adopt alternative landscape aesthetics (Feagan and Ripmeester, 2001).

Turfgrass lawns are a symbol for a good neighborhood and signify the pride that individuals (and by extension, the neighborhood) place in their home and themselves. Alternative landscapes have been documented as being viewed as out-of-place and as a site of pollution for weeds, leaves, debris, and pests. Such notions of polluting extend to a symbolic polluting of the neighborhood aesthetic. Much landscaping behavior is focused on maintaining norms and traditions (Feagan and Ripmeester, 1999), and the prestige offered by the home lawn impacts landscape preference. When given an option between a desert (non-turf), mesic (turfgrass), or oasis (mix of two) in Phoenix, AZ, $70 \%$ of respondents preferred a landscape design that included some turfgrass (either mesic or oasis) (Martin et al., 2003), although more recent research in Santa Fe, NM, has shown a shift away from a turfgrass preference. Only $39 \%$ of respondents agreed that grass was desirable for landscaping, with $89 \%$ of respondents agreeing that grass requires a lot of maintenance. Conversely, $78 \%$ of respondents desired high desert plants and $96 \%$ desired trees (St. Hilaire et al., 2010). Although one survey in southeast Michigan found people were willing to pay more for well-designed yards with native plants than they were for lawns (Helfand et al., 2006), the personal values of the neighborhood may prove more powerful (Nassauer, 1995). Although an individual may value wildlife in his or her landscape, the individual is unlikely to change the landscape aesthetic if it conflicts with the desires of the neighborhood (Nassauer, 1995). A notion of individual autonomy over landscape behavior must be tempered with an understanding of the competing power structures that ultimately drive a desire (or aversion) for a particular landscape aesthetic and the practices that an individual takes in manifesting (or preventing) and maintaining (or neglecting) that aesthetic.

Florida has a controversial history related to the adoption of lawn and landscape fertilizer ordinances, many of which prohibit nitrogen $(\mathrm{N})$ and phosphorus $(\mathrm{P})$ application during certain months of the year, often termed fertilizer blackout periods. The first such ordinance was adopted in St. John's County on 25 Jan. 2000 and prohibited the application of quick-release $\mathrm{N}$ materials to "any grass, plant, or other organic material" from 15 May to 31 Oct. in certain specified unincorporated county areas. Although exceptions were made for agricultural purposes, golf greens, establishing turf, and supervised fertigation systems, applications outside of these scenarios were classified as a misdemeanor and could potentially yield a 60 -d jail sentence. Almost immediately, concern and condemnation were expressed from turfgrass faculty at the University of Florida (UF), as well as representatives from both the golf and landscape industries (Busey et al., 2000). Although this ordinance would be revised twice more before the end of the year, and eventually repealed, replaced, and repealed, and replaced again (Ryan, 2016), it marked a significant turning point in landscape and lawn fertilizer policy in Florida.

The third edition of the Florida Yards \& Neighborhoods (FYN) program handbook, titled $A$ Guide to Florida-Friendly Landscaping (FYN, 2006), provided information regarding lawn fertilization timing. This guidebook, published by the UF Institute for Food and Agricultural Science (IFAS) Department of Environmental Horticulture, stated that in some parts of the state, lawns undergo a dormant period during part of the year, whereas in other parts of the state growth occurs year-round. Fertilizer should be applied during periods of active growth (the summer), but that quantity should be limited in summer months "when grass is already growing rapidly." Instead, the advice is given of applying a chelated iron or iron sulfate to induce greening without increasing growth. The section advises consulting a UF/IFAS county extension office with questions related to lawn fertilization (FYN, 2006). Overall, the FYN program is centered on nine principles of landscaping practice, only one of which is focused on fertilization. These nine principles would later be adopted by the Florida-Friendly Landscaping (FFL) program (FFL, n.d.-a; FYN, 2006).

In 2007, Sarasota County adopted a summertime fertilizer blackout ordinance, prohibiting the application of $\mathrm{N}$ and $\mathrm{P}$ fertilizers to lawns and landscapes from 1 June to 30 Sept. Lee County would follow suit in 2008 (Ryan, 2016). In 2008, the FFL program was established to serve both homeowners and commercial horticulture professionals. The FFL program formed as a combination of the existing FYN program HomeOwner and FYN Builder and Developer programs, as well as the Florida-Friendly Best Management for Protection of Water Resources by the Green Industries (GI-BMP). The FFL program is structured under the UF/IFAS Center for Landscape Conservation \& Ecology (CLCE) (FFL, n.d.-b).

In Mar. 2009, UF published a document on their Electronic Data Information Source (EDIS) of UF/IFAS Extension titled "Urban Water Quality and Fertilizer Ordinances: Avoiding Unintended Consequences: A Review of the Scientific Literature." This document is largely a literature review and describes the many causes of eutrophication before focusing on fertilizer and nutrient management in the urban landscape. The article concludes that the fertilizer restrictive periods in Florida may not necessarily improve urban water quality (Hochmuth et al., 2009). In July 2010, a representative for the Sierra Club Florida (headquarters in St. Petersburg, FL) submitted a public records request for e-mails to gain access to the reviewers for this EDIS publication with allegations of corrupt science and collusion with industry, 
arguing that the publication contradicts previous university guidelines for landscaping. The UF response was that reviewers and document drafts are not subject to public record release as "there is a public interest in protecting the academic freedom of researchers." In total, the request resulted in 42,180 pages of documents that would need to be printed and reviewed by legal counsel at a cost of $\$ 24,000$. With this cost being prohibitively high, the Sierra Club Florida decided to move forward with a lawsuit against UF in Sept. 2011 (Crabbe, 2011), to which there has been no apparent outcome. A revised version of the EDIS document would later be published in the peer-reviewed academic journal HortTechnology (Hochmuth et al., 2012).

As of 2019, the Sierra Club Florida represents a chapter of the national Sierra Club and is composed of volunteer leaders and civic activists. The Sierra Club Florida is composed of 16 localized volunteer groups across the state with a statewide membership of more than 37,700 . The stated mission of the group is to "enjoy, explore and protect the natural places in Florida, to teach others to understand and respect the fragile environment in which we live, and to practice and promote the responsible use of Florida's ecosystems and resources" (Sierra Club Florida, 2019). The Sierra Club Florida continued to be a driving force in the adoption and preservation of seasonal landscape fertilizer bans. In 2012, they held rallies and protests in multiple Florida cities (Valtin, 2012). Facing the possibility of a state bill exempting professional applicators from being subject to seasonal fertilizer restrictions (Tampa Bay Times, 2012) protesters held signs stating "Local Control of Local Pollution! No on HB421!" and "Green Slime = Bad for Business," and the proposed bill was eventually tabled (Valtin, 2012). In 2013, 99 Florida manatees (Trichechus manatus ssp. latirostris) were found dead due to eutrophication in the Indian River Lagoon, and despite fertilizer blackout periods already enacted along this area, the Sierra Club Florida placed blame on lawn fertilizers (WESH Orlando, 2013). Of course, both the overall compliance and effectiveness of these ordinances is worth considering. Beginning in 2014, lawn and landscape commercial fertilizer applicators were required to obtain a license from the Florida Department of Agriculture and Consumer Services, which necessitated the successful completion of GI-BMP training as administered by UF/IFAS and the Florida Department of Environmental Protection (FDEP) (FFL, n.d.-c).

The Florida turfgrass industry felt unjustly targeted as the culprit of this environmental degradation, and remained particularly concerned regarding the spread of restrictive fertilizer blackout ordinances. In part to counter the rhetoric of such environmental activism, the Environmental Research and Education Foundation (EREF) was formed with the stated goal of "working with local citizens and elected officials to address real solutions for water conservation and water quality," naming support from various Florida turfgrass, golf, and landscape organizations (EREF, n.d.). In a presentation at the 2015 Florida Turfgrass Association Conference and Tradeshow, the Executive Director for EREF described his experiences dealing with public protest during policy hearings regarding these ordinance adoptions, emphasizing the importance of staying on message, being rational, having confidence, and prior preparation to counter the undisciplined, screaming response of the opposition, stating that UF faculty had been treated with disrespect and called industry shills (M. Carraway, unpublished).

These descriptions represent the explicit language of the presentation and serve as representation for the tone of discourse regarding industry and university faculty that find themselves in political conflict with environmental activism. Ultimately, the presentation framed the discourse as being one of uncontrolled emotion vs. reasoned and calm preparation (M. Carraway, unpublished), although such a claim is misleading to the emotionality and rationality for all involved. A lawsuit and allegations of professional and academic corruption are most surely personal, having strong and consequential emotional impact, whereas a desire to save polluted environments is among one of the most reasonable stances a person can take, with the necessary activism requiring deliberation, coordination, and forethought to conduct. To date, more than 100 lawn and landscape fertilizer ordinances have been adopted in counties and municipalities across Florida, with more than half of these ordinances prohibiting the application of $\mathrm{N}$ or $\mathrm{P}$ during certain months of the year (Ryan, 2016).

To understand factors related to policy adoption and differences between Florida residents and decision makers, we determined the following objectives. The first objective was to describe Florida residents and decision makers' sentiments about turfgrass, levels of turfgrass maintenance, and trust in landscape science. The second objective was to determine the percentage of Florida residents and decision makers who could accurately identify the blackout status of the city or county in which they live. The third objective was to determine if there are differences between Florida residents and decision makers in terms of self-identifying as living in a city or county with a blackout, their accuracy in identifying as living in a city or county with a blackout, sentiments about turfgrass, levels of turfgrass maintenance, and trust in landscape science.

\section{Methods}

For this research, we surveyed two populations: Florida residents and Florida decision makers. The first survey was aimed at Florida residents and was part of a larger annual webbased water perception survey conducted by the UF/IFAS Center for Public Issues Education (PIE) for Agricultural and Natural Resource (Lamm, 2013). Before distribution, this survey instrument was reviewed to assess validity by the director of the PIE Center, as well as by the director of the UF Water Institute, the director of the UF/IFAS CLCE, and an extension evaluation specialist. Finally, institutional review board (IRB) approval was obtained through UF.

The survey was distributed using statistical survey software (Qualtrics, Provo, UT/Seattle, WA). The survey was administered to Florida residents older than 18 years in Dec. 2015, and participation was incentivized with a points-accumulating system, allowing participants to gain points from completing surveys, which could then 
be exchanged for gift cards. As this survey provided compensation for completion, attention filters were used, which prompted respondents to select a specific answer to prevent individuals from simply completing the survey quickly with false answers.

The survey yielded a response rate of $58 \%$, with 523 responses considered complete of 986 surveys distributed. Following data collection, respondents had their responses weighted based on 2010 U.S. Census Data using post stratification methods (Baker et al., 2013; Kalton and Flores-Cervantes, 2003). We analyzed data using both the $\mathrm{R}$ programming language in an opensource, free user-interface (RStudio, Boston, MA) and with statistical software (SPSS version 24.0; IBM Corp, Armonk, NY). We used existing questions contained within the annual water survey instrument for this research (such as ones that collected demographic information), although additional questions related to fertilizer ordinances, turfgrass maintenance practices, as well as five-point Likert scales assessing turfgrass sentiments and trust in landscape science were also created and included.

We created a series of questions gauging the diversity of possible turfgrass maintenance practices by consulting with turfgrass science faculty at UF. The turfgrass sentiment scale was created based on existing literature to assess how respondents felt about turfgrass and its use in the landscape. The trust in landscape science scale was adapted from a previously constructed trust in science scale (National Science Board, 2014). For both scales, Cronbach's alpha was calculated ex post facto to assess interscale reliability, and the scales were found to be reliable based on obtained values (Cronbach, 1951). Finally, to obtain indices from the scales, individual responses were averaged, with specific prompts being reverse-coded when necessary. As respondents provided the zip code in which they resided, and municipal and county policies cross zip code boundaries, the few individuals whose zip code could fall under different policies were dropped from relevant data analysis.

In Summer 2016, we conducted a second survey aimed at Florida decision makers. An e-mail list previously compiled through the UF/ IFAS PIE Center was used that included county clerks, commissioners, and managers (Taylor and Lamm, 2016). IRB approval was obtained through UF, and on survey distribution, decision makers were asked to take a voluntary, nonincentivized survey. As survey participation was voluntary and noncompensated, and the survey was intentionally brief, responses were assumed to be genuine and accurate.

We sent out an invitation e-mail in mid-June 2016. An initial 1243 e-mails were sent, with 82 e-mails bouncing, bringing the total number of successful distributions to 1161 . Reminder e-mails were distributed to incomplete/not-started respondents every 2 weeks until mid-July, allowing participants $\approx 1.5$ months to complete the survey. We modeled both the initial invitation e-mail and reminder e-mails after examples provided by Dillman et al. (2009). A total of 218 individuals started the survey, with 171 individuals completing the survey, although participants could skip questions, resulting in a small portion of completed responses not answering all questions. A final response rate of $14.7 \%$ was obtained based on valid e-mail addresses and complete responses.

Statistical analysis. Data were processed using the $\mathrm{R}$ programming language in R Studio and using SPSS statistical software. Minor data cleaning was necessary on qualitative data responses, such as zip code, where erroneous entries (often the result of minor user input errors) could be removed or fixed as appropriate. Furthermore, individuals with partial responses on certain questions were removed from analysis for these prompts. Scales were determined to have interscale reliability based on Cronbach's alpha, and indices were obtained from these scales. For all results stated, a significance threshold was set at $P<0.05$. A $\chi^{2}$ test was used to compare survey respondents with the entire surveyed population of decision makers based on region of the state they resided, as well as sex, and no significant differences were found for either metric, allowing obtained responses to be generalized to the larger population of Florida decision makers.

\section{Results}

LAWNCARE MAINTENANCE DATA. Respondents in both the Florida resident and Florida decision-maker groups were asked to select all the listed lawncare maintenance practices they performed on their own personal lawn. Before viewing this question, participants were screened based on whether they had a yard, and then again, on whether their lawn had turfgrass. For Florida resident respondents, $28.6 \%$ stated they had a yard, with no turfgrass, and $26.1 \%$ of Florida decision makers responded the same. In contrast, $30.3 \%$ of Florida resident respondents, and $6.2 \%$ of Florida decision-maker respondents had no yard at all. Almost no one with a turfgrass yard had no maintenance practices (1.0\% for Florida resident respondents, $0.0 \%$ for Florida decision-maker respondents) (Table $\mathrm{l}$ ).

A $\chi^{2}$ test was conducted to determine if there were differences between the groups in terms of the number of maintenance practices. Individuals were grouped into low $(0-2$ practices), medium (3-5), and high (68 ) maintenance categories. Individuals without yards or without turfgrass were excluded. Differences were found in the number of lawncare practices between the two populations, with residents having a mean number of 3.82 practices and decision makers having a mean number of 4.64 practices.

For individuals who stated they had turfgrass yards, mowing was the most common maintenance practice for both resident respondents and for decision-maker respondents, with $\mathbf{9 5 . 6 \%}$ of residents and $99.1 \%$ of decision-maker respondents using the practice. Other common practices included applying herbicides (48.9\% for both groups), applying insecticides (51.8\% for residents, $49.5 \%$ for decision makers), and hand-pulling of weeds $(60.1 \%$ for residents, $83.5 \%$ for decision makers) (Table 2). Fisher's exact test was used to determine significant differences between specific maintenance practices, and differences were found for the application of fertilizers (48.9\% for residents, $33.0 \%$ for decision makers), hand-pulling of weeds $(60.1 \%$ for residents, $83.5 \%$ for decision makers), and automated irrigation using a timer to water their lawn $(36.5 \%$ for residents, $61.5 \%$ for decision makers) (Tables 2 and 3 ). 
Table 1. Percentages for number of lawncare maintenance practices for Florida residents $(n=523)$ and Florida decision makers $(n=161)$.

\begin{tabular}{lcc}
\hline $\begin{array}{l}\text { Lawncare maintenance } \\
\text { practices (no.) }\end{array}$ & $\begin{array}{c}\text { Florida resident } \\
\text { respondents }(\%)^{\mathbf{z}}\end{array}$ & $\begin{array}{c}\text { Florida decision-maker } \\
\text { respondents (\%) }\end{array}$ \\
\hline 0 (but has turfgrass yard) & 1.0 & 0.0 \\
1 & 5.6 & 2.5 \\
2 & 8.1 & 8.7 \\
3 & 4.4 & 8.7 \\
4 & 5.5 & 9.9 \\
5 & 5.5 & 13.0 \\
6 & 6.7 & 13.0 \\
7 & 2.4 & 9.3 \\
8 & 1.9 & 2.5 \\
Has a yard, but it does not & 28.6 & 26.1 \\
have turfgrass & & 6.2 \\
Has no yard & 30.3 & \\
\hline
\end{tabular}

${ }^{2}$ For Florida resident respondents and for respondents with turfgrass in their yard, the mean number of practices $( \pm$ $\mathrm{SD}$ ) was $3.82 \pm 2.14$. For Florida decision-maker respondents and for respondents with turfgrass in their yard, the mean number of practices was $4.64 \pm 1.84$.

Table 2. Percentages for different lawncare maintenance practices for Florida residents and Florida decision makers for individuals with turfgrass in their yards.

\begin{tabular}{|c|c|c|}
\hline $\begin{array}{l}\text { Lawncare maintenance } \\
\text { practice }\end{array}$ & $\begin{array}{l}\text { Florida resident } \\
\text { respondents (\%) }\end{array}$ & $\begin{array}{l}\text { Florida decision-maker } \\
\text { respondents valid (\%) }\end{array}$ \\
\hline Application of fertilizers & 48.9 & 33.0 \\
\hline $\begin{array}{l}\text { Application of herbicides / } \\
\text { weed killers }\end{array}$ & 48.9 & 48.9 \\
\hline $\begin{array}{l}\text { Application of insecticides / } \\
\text { insect killer }\end{array}$ & 51.8 & 49.5 \\
\hline $\begin{array}{l}\text { Application of fungicides / } \\
\text { disease Killer }\end{array}$ & 20.5 & 23.9 \\
\hline Mowing & 95.6 & 99.1 \\
\hline Hand-pulling of weeds & 60.1 & 83.5 \\
\hline $\begin{array}{l}\text { Automated irrigation using } \\
\text { a timer to water your lawn }\end{array}$ & 36.5 & 61.5 \\
\hline $\begin{array}{l}\text { Manually running an irrigation } \\
\text { system }\end{array}$ & 19.3 & 26.6 \\
\hline None of the above & 2.5 & 0.0 \\
\hline
\end{tabular}

Table 3. Fisher's exact test to determine significant differences between Florida resident respondents and Florida decision-maker respondents for specific maintenance practices.

\begin{tabular}{lc}
\hline Practice & $P$ \\
\hline Hand-pulling of weeds & $0.00^{* * *}$ \\
Automated irrigation using a timer to water your & $0.00^{* * *}$ \\
$\quad$ lawn & $0.00^{* *}$ \\
Application of fertilizers & 0.16 \\
Manually running an irrigation system & 0.17 \\
None of the above & 0.17 \\
Mowing & 0.48 \\
Application of fungicides/disease killer & 0.48 \\
Application of herbicides/weed killers & 0.73 \\
Application of insecticides/insect killer &
\end{tabular}

$* *,{ }^{* *}$ Significant at $P \leq 0.01$ or 0.001 , respectively.

LIKERT SCALE DATA. Trust in landscape science by Florida residents generally tended toward a positive response, with the highest percentages being in the agree category (Table 4 ). Cronbach's alpha values were calculated for both residents and decision makers and were found to be above
0.70 for both groups, confirming interscale reliability (Cohen, 1988). The means between the two populations were found to be significantly different, with Florida resident respondents having a mean response of 3.49, whereas Florida decisionmaker respondents indicated greater trust, with a mean response of 3.80 (Table 5).

When considering turfgrass sentiments, both Florida resident respondents and Florida decisionmaker respondents primarily selected "neither agree nor disagree" for each question (Table 6). One statement was an exception to this trend, which read "I appreciate when homes in a neighborhood all have well-maintained lawns." Both respondent groups were more likely to agree (69.3\% of resident respondents either agreed or strongly agreed, compared with $79.4 \%$ of decision-maker respondents) (Table 6). Regarding the statement that "turfgrass lawns have an overall negative impact on water quality of nearby water bodies," $20.0 \%$ of Florida resident respondents agreed with this statement, compared with $34.2 \%$ for Florida decision-maker respondents (Table 6). Despite these differences in individual responses, the mean response for the overall scale was similar between the two populations (3.00 for residents and 2.97 for decision makers) presenting a neutral stance on turfgrass sentiments. No differences were found between the mean response of the two populations (Table 5). Cronbach's alpha was found to be above a 0.70 value for both residents and decision makers, verifying interscale reliability (Table 5 ).

IDENTIFYING BLACKOUT POLICY. When asked, "Is there a fertilizer restrictive period (i.e., blackout) policy for lawns/landscapes enacted in the county or city in which you live?", $10.9 \%$ of Florida resident respondents stated "yes," compared with $23.4 \%$ of Florida decision-maker respondents. Fewer than half $(42.1 \%)$ of Florida resident respondents stated "no," compared with $64.3 \%$ of Florida decision-maker respondents. Last, $47.0 \%$ of Florida resident respondents stated "unsure," compared with $12.3 \%$ of Florida decision-maker respondents. Using a $\chi^{2}$ test, these responses were found to be different between the two populations (Table 
Table 4. Trust in landscape science scale for Florida resident respondents and Florida decision-maker respondents.

\begin{tabular}{|c|c|c|c|c|c|c|c|c|c|c|}
\hline \multirow[b]{2}{*}{ Statement } & \multicolumn{5}{|c|}{ Florida resident respondents } & \multicolumn{5}{|c|}{ Florida decision-maker respondents } \\
\hline & $\begin{array}{c}\text { Strongly } \\
\text { disagree } \\
(\%)\end{array}$ & $\begin{array}{c}\text { Disagree } \\
(\%)\end{array}$ & $\begin{array}{c}\text { Neither } \\
\text { agree nor } \\
\text { disagree } \\
(\%)\end{array}$ & $\begin{array}{c}\text { Agree } \\
(\%)\end{array}$ & $\begin{array}{c}\text { Strongly } \\
\text { agree (\%) }\end{array}$ & $\begin{array}{c}\text { Strongly } \\
\text { disagree } \\
(\%)^{\mathrm{z}}\end{array}$ & $\begin{array}{c}\text { Disagree } \\
(\%)^{\mathrm{z}}\end{array}$ & $\begin{array}{c}\text { Neither } \\
\text { agree nor } \\
\text { disagree } \\
(\%)^{\mathrm{z}}\end{array}$ & $\begin{array}{c}\text { Agree } \\
(\%)^{\mathrm{z}}\end{array}$ & $\begin{array}{c}\text { Strongly } \\
\text { agree }(\%)^{\mathrm{z}}\end{array}$ \\
\hline $\begin{array}{l}\text { Developments in } \\
\text { science lead to } \\
\text { healthier urban } \\
\text { landscapes. }\end{array}$ & 1.4 & 3.3 & 35.7 & 47.8 & 11.7 & 0.6 & 2.6 & 18.8 & 57.8 & 20.1 \\
\hline $\begin{array}{l}\text { Scientists } \\
\text { contribute to } \\
\text { a better } \\
\text { understanding } \\
\text { of turfgrass } \\
\text { lawn } \\
\text { management. }\end{array}$ & 0.9 & 4.2 & 39.9 & 46.0 & 9.9 & 0.6 & 1.9 & 14.9 & 63.6 & 18.8 \\
\hline $\begin{array}{l}\text { Scientific } \\
\text { research is } \\
\text { essential for } \\
\text { improving the } \\
\text { quality of } \\
\text { landscapes. }\end{array}$ & 1.2 & 4.7 & 43.5 & 40.0 & 10.6 & 1.3 & 3.3 & 22.9 & 52.3 & 20.3 \\
\hline $\begin{array}{l}\text { Americans } \\
\text { should value } \\
\text { their feelings } \\
\text { over science } \\
\text { when it comes } \\
\text { to managing } \\
\text { their lawns. } \\
\end{array}$ & 8.0 & 13.3 & 44.7 & 26.6 & 7.4 & 11.8 & 28.9 & 34.2 & 18.4 & 6.6 \\
\hline
\end{tabular}

7). While the stated responses varied, a $\chi^{2}$ test did not identify actual differences between the two populations in terms of their actual policy (Table 8).

When considering the accuracy of these responses, $31.5 \%$ of Florida resident respondents accurately identified their policy $(6.2 \%$ were accurate about being in a blackout city/ county, 25.3\% were accurate about not being in a blackout city/county). In contrast, $80.5 \%$ of Florida decision-maker respondents accurately identified their policy $(21.4 \%$ were accurate about being in a blackout city/county, 59.1\% were accurate about not being in a blackout city/ county). For Florida resident respondents, $16.4 \%$ were inaccurate when identifying if they reside in a blackout city/county (11.6\% inaccurately thought they were in a blackout city/ county, $4.8 \%$ inaccurately thought they were not in a blackout city/ county). In contrast, only $6.4 \%$ of
Florida decision-maker respondents were inaccurate about their identification $(4.5 \%$ inaccurately thought they were in a blackout city/county, $1.9 \%$ inaccurately thought they were not in a blackout city/county). Florida resident respondents were more likely to state they were unsure compared with Florida decision-maker respondents. Just over half (51.9\%) of Florida resident respondents were unsure about if they were in a blackout city/county $(21.1 \%$ of these were in 
a blackout city/county and $30.8 \%$ were not). Only $13.0 \%$ of Florida decision-maker respondents stated that they were unsure about the existence of a blackout where they live
(3.9\% were in a blackout city/county, and $9.1 \%$ were not) (Table 9 ). A $\chi^{2}$ test identified significant differences between residents and decision makers in their accuracy of response.

Table 5. Summary of survey indices related to trust in landscape science and turfgrass sentiments for both Florida residents and decision-maker respondents.

\begin{tabular}{|c|c|c|c|c|}
\hline \multirow[b]{2}{*}{ Measure $^{\mathrm{z}}$} & $\begin{array}{c}\text { Trust in } \\
\text { landscape science }\end{array}$ & \multirow{2}{*}{$\begin{array}{c}\text { Trust in } \\
\text { landscape science } \\
\begin{array}{c}\text { Florida decision } \\
\text { makers }\end{array}\end{array}$} & \multirow{2}{*}{$\begin{array}{c}\begin{array}{c}\text { Turfgrass } \\
\text { sentiments }\end{array} \\
\begin{array}{c}\text { Florida } \\
\text { residents }\end{array} \\
\end{array}$} & \multirow{2}{*}{$\begin{array}{c}\text { Turfgrass } \\
\text { sentiments } \\
\begin{array}{c}\text { Florida decision } \\
\text { makers }\end{array}\end{array}$} \\
\hline & Florida residents & & & \\
\hline $\mathrm{N}$ & 523 & 154 & 523 & 157 \\
\hline M & 3.49 & 3.80 & 3.00 & 2.97 \\
\hline SD & 0.52 & 0.57 & 0.62 & 0.83 \\
\hline$A$ & 0.79 & 0.71 & 0.78 & 0.74 \\
\hline
\end{tabular}

${ }^{\mathrm{z}} \mathrm{N}=$ sample size; $\mathrm{M}=$ mean value [Analysis of variance was used to determine significant differences between means. The means were found to be different for trust in landscape science but were not found to be different for turfgrass sentiments $(P=0.64)$. Mean values for indices were created from Likert scale data by averaging respondents' answers and creating a mean response value from these responses. ]; $\mathrm{SD}=$ standard deviation of the values; $\mathrm{A}=$ Cronbach's alpha, used to assess interscale reliability

\section{Discussion}

LaWNCARE MAINTENANCE. This research revealed that $61.5 \%$ of Florida decision-maker respondents and $36.5 \%$ of Florida resident respondents used an automated irrigation system to water their lawn, with $26.6 \%$ of the decision-maker population and $19.3 \%$ of the resident population also stating they manually ran their irrigation systems. These findings contrast with survey research in the Glyndon watershed, Maryland, which found $48 \%$ of homeowners watered their lawn, with only $9 \%$ of homeowners in the Baisman Run watershed in Maryland, watering their lawn (Law et al., 2004). Although this survey does not identify the regularity of watering practices, these results may suggest

Table 6. Turfgrass sentiments scale for Florida resident respondents and Florida decision-maker respondents.

\begin{tabular}{|c|c|c|c|c|c|c|c|c|c|c|}
\hline \multirow[b]{2}{*}{ Statement } & \multicolumn{6}{|c|}{ Florida resident respondents } & \multicolumn{4}{|c|}{ Florida decision-maker respondents } \\
\hline & $\begin{array}{c}\text { Strongly } \\
\text { disagree } \\
(\%) \\
\end{array}$ & $\begin{array}{c}\text { Disagree } \\
(\%)\end{array}$ & $\begin{array}{l}\text { Neither } \\
\text { agree nor } \\
\text { disagree } \\
(\%)\end{array}$ & $\begin{array}{c}\text { Agree } \\
(\%)\end{array}$ & $\begin{array}{l}\text { Strongly } \\
\text { agree (\%) }\end{array}$ & $\begin{array}{c}\text { Strongly } \\
\text { disagree } \\
(\%)^{\mathrm{z}}\end{array}$ & $\begin{array}{c}\text { Disagree } \\
(\%)^{\mathrm{z}}\end{array}$ & $\begin{array}{c}\text { Neither } \\
\text { agree nor } \\
\text { disagree } \\
(\%)^{\mathrm{z}}\end{array}$ & $\begin{array}{c}\text { Agree } \\
(\%)^{\mathrm{z}}\end{array}$ & $\begin{array}{c}\text { Strongly } \\
\text { agree }(\%)^{\mathrm{z}}\end{array}$ \\
\hline $\begin{array}{l}\text { Turfgrass lawns } \\
\text { have an overall } \\
\text { negative impact } \\
\text { on the water } \\
\text { quality of } \\
\text { nearby water } \\
\text { bodies. }{ }^{y, x}\end{array}$ & 4.8 & 10.9 & 64.4 & 13.4 & 6.6 & 3.2 & 10.0 & 42.6 & 18.1 & 16.1 \\
\hline $\begin{array}{l}\text { I think too many } \\
\text { people have } \\
\text { turfgrass lawns. }{ }^{x}\end{array}$ & 6.3 & 19.7 & 54.5 & 12.8 & 6.7 & 8.5 & 19.6 & 46.4 & 9.8 & 15.7 \\
\hline $\begin{array}{l}\text { I prefer native } \\
\text { plants over } \\
\text { turfgrass lawns. }{ }^{x}\end{array}$ & 3.3 & 9.9 & 44.3 & 30.0 & 12.5 & 3.9 & 13.7 & 38.6 & 24.8 & 19.0 \\
\hline $\begin{array}{l}\text { I feel turfgrass } \\
\text { lawns are } \\
\text { unnatural. }\end{array}$ & 5.0 & 20.8 & 50.6 & 16.7 & 6.9 & 4.6 & 33.3 & 39.9 & 13.7 & 8.5 \\
\hline $\begin{array}{l}\text { Most people put } \\
\text { too many } \\
\text { resources into } \\
\text { managing their } \\
\text { turfgrass lawns. }^{\mathrm{x}}\end{array}$ & 3.0 & 10.8 & 54.0 & 22.0 & 10.1 & 3.2 & 15.6 & 37.0 & 26.0 & 18.2 \\
\hline
\end{tabular}


Table 7. Responses from Florida resident respondents $(\mathbf{n}=\mathbf{5 2 3})$ and Florida decision-maker respondents $(n=154)$ to the question, "Is there a fertilizer restrictive period (i.e., blackout) policy for lawns/landscapes enacted in the county or city in which you live?"

\begin{tabular}{lcc}
\hline Response & $\begin{array}{c}\text { Florida resident } \\
\text { respondent (\%) }\end{array}$ & $\begin{array}{c}\text { Florida decision-maker } \\
\text { respondent (\%) }\end{array}$ \\
\hline Yes & 10.9 & 23.4 \\
No & 42.1 & 64.3 \\
Unsure & 47.0 & 12.3 \\
\hline
\end{tabular}

Table 8. Actual blackout status of zip codes for Florida resident respondents $(\mathbf{n}=$ 516) and decision-maker respondents $(n=160) .^{\mathrm{z}}$

\begin{tabular}{lcc}
\hline Actual status & $\begin{array}{c}\text { Florida resident } \\
\text { respondents (\%) }\end{array}$ & $\begin{array}{c}\text { Florida decision-maker } \\
\text { respondents (\%) }\end{array}$ \\
\hline Blackout & 39.0 & 31.3 \\
No blackout & 61.0 & 68.8 \\
\hline
\end{tabular}

${ }^{2} \chi^{2}$ test found $P=0.32$, meaning no significant difference between the populations.

Table 9. Determining the accuracy of self-reported response to living within a city or county with a fertilizer restrictive period (i.e., blackout) policy for lawns/landscapes for Florida resident respondents $(n=516)$ and Florida decision-maker respondents $(\mathbf{n}=\mathbf{1 5 4})$.

\begin{tabular}{lcc}
\hline Accuracy of response & $\begin{array}{c}\text { Florida resident } \\
\text { respondent (\%) }\end{array}$ & $\begin{array}{c}\text { Florida decision-maker } \\
\text { respondent (\%) }\end{array}$ \\
\hline $\begin{array}{l}\text { Response correct: actually in } \\
\text { a blackout area }\end{array}$ & 6.2 & 21.4 \\
$\begin{array}{l}\text { Response correct: not actually in } \\
\text { a blackout area }\end{array}$ & 25.3 & 59.1 \\
$\begin{array}{l}\text { Response incorrect: actually in } \\
\text { a blackout area }\end{array}$ & 11.6 & 4.5 \\
$\begin{array}{l}\text { Response incorrect: not actually } \\
\text { in a blackout area }\end{array}$ & 4.8 & 1.9 \\
$\begin{array}{l}\text { Unsure: actually in a blackout } \\
\text { area }\end{array}$ & 21.1 & 3.9 \\
$\begin{array}{l}\text { Unsure: not actually in } \\
\text { a blackout area }\end{array}$ & 30.8 & 9.1 \\
\hline
\end{tabular}

differences between lawn management practices between different locations, emphasizing the need for localized outreach regarding management practices, especially among different populations. Research across six U.S. cities found that despite natural variation in precipitation and aridity, irrigation practices were relatively homogeneous. Such homogenization was also seen in fertilization practice in contrast to natural variation in soil $\mathrm{N}$ content (Groffman et al., 2016).

For Florida resident respondents with lawns, $48.9 \%$ fertilized their lawns, compared with $33.0 \%$ of Florida decision-maker respondents. In addition, this difference between resident respondents and decision-maker respondents was found to be significant. These numbers contrast with survey work done in three counties in the Tampa Bay area of Florida, where $60 \%$ of homeowners were found to fertilize their lawn (Souto et al., 2019). Previous research found that fertilization can be predicted based on whether one's neighbor fertilizes (Martini et al., 2015), with fertilization application rate also being predicted by living in an HOA (Fraser et al., 2013) and by increased lot and property size (Martini et al., 2015). Ultimately, Florida decision makers are responsible for adopting policy related to lawn/landscape fertilization for populations that fertilize at lower rates than they themselves do. As such, it is likely their perceptions of lawn and landscape fertilization practices may not be in line with the actual practices of Florida residents.

The survey found that $28.6 \%$ of resident respondents and $26.1 \%$ of decision-maker respondents stated that they had a yard with no turfgrass. A limitation to this research was the respondents' understanding of the term turfgrass. Although a turfgrass lawn was defined for respondents as "grasses that form a dense, even ground cover if mowed and maintained," this definition was not provided until later in the survey, which might explain these response outcomes. That said, although turfgrass landscapes dominate in the state, the overall quality and substance of these landscapes varies considerably. Krishnaswami and Merton (2015) conducted a photographic survey of neighborhoods in south-central St. Petersburg, FL, and found that neglected yards represented $63 \%$ of the sampled yards. These neglected yards were somewhat modeled after the ideal American lawn, but due to low or no maintenance, they exhibited brown or patchy turf, and/or bare soil conditions, particularly in the dry winter months. Mustafa et al. (2010) corroborate these findings with visual survey work in St. Petersburg, FL, confirming the dominance of turfgrass lawns, but categorizing 65\% as low input. It is possible that individuals with such neglected yards may not identify as having a turfgrass yard. For Krishnaswami and Merton (2015), lush lawns were found to comprise only $8 \%$ of the survey sample, with modest lawns and mixed lawns representing $17 \%$ and $8 \%$, respectively. Florida-friendly and xeric yards were in the minority, with only $3 \%$ of the sampled yards being of this type.

Socioeconomic demographics also may play a role in the adoption of alternative landscapes. Johns (2008) found that individuals with higher education in Pinellas County, FL, were more likely to favor FFL (which may include non-turfgrassfocused aesthetics), whereas non-college graduates were less likely to be aware of such landscaping practices. That said, Krishnaswami and Merton (2015) found that income was not found to necessarily be connected with the neglected yard type, as both the highest quarter and lowest quarter of income neighborhoods exhibited similar rates of neglect (66\% and 65\%, respectively). Even so, the individual poorest neighborhoods did have higher rates of neglect than the wealthiest neighborhoods. 
Similarly, Mustafa et al. (2010) found that having a xeriscaped landscape did not increase proportional to income in St. Petersburg, FL.

TURfgrass SENTIMENTS AND TRUST IN SCIENCE. This research found that Florida decision-maker respondents are more trusting of landscape science than Florida residents. In the northeastern United States, survey data conducted on recreational anglers found that, related to fishery management, recreational anglers had lower levels of trust in scientific assessments than they did in government agencies, with the authors speculating that the lower trust in scientific assessments may be due to science informing unfavorable policy outcomes (Gray et al., 2012). It may be assumed that decision makers would inherently have a higher level of political knowledge than the average resident, and research found that an increase in political knowledge led to an increase in trusting science (Sturgis and Allum, 2004).

Two dominant models for conceptualizing the public's relationship with science have been identified. The first is one of deficit, in which skepticism against science is due to a lack of understanding of science. Emphasis is placed on both scientific knowledge and methods. The second model for conceptualizing the public's relationship with science relies on contextualization. Although it includes the components of the first model, it emphasizes how organizations and individuals engage with science differently depending on context. The scientific claims being made may be received and interpreted differently based on who is making them (Sturgis and Allum, 2004). In this way, assessing the trust in landscape scale is inherently contextualized in an academic setting as administered by UF. As Florida decision-maker respondents had higher levels of education (data not shown), this context may be more familiar and trustworthy.

Both Florida resident respondents and Florida decision-maker respondents remained neutral in terms of their turfgrass sentiments, with a mean response of 3.00 for Florida resident respondents and 2.97 for Florida decision-maker respondents, with no significant difference between these two populations. Although previous research has described a notable polarized discourse (Feagan and Ripmeester, 2001), the neutral means along with the relatively low standard deviation for the two populations (0.62 for Florida resident respondents and 0.83 for Florida decision-maker respondents) suggested that both residents and decision makers held generally neutral views surrounding turfgrass. Although polarized ideology may exist, these data suggest it is not the norm.

Blackout policy. Data analysis revealed that Florida decision-maker respondents were representative of the larger statewide decision-maker population in terms of region of the state resided. Therefore, it was expected there would be no significant difference in actual blackout status between the Florida resident respondents and Florida decisionmaker respondents, which was confirmed by the data. Furthermore, no differences in terms of response for identified blackout status were expected, yet differences were found in both identified blackout status of resided city/county, as well as accuracy of these beliefs between the two survey populations. Florida resident respondents had higher rates of identifying as being unsure if blackout policy was in their resided city/ county ( $47 \%$ vs. $12.3 \%$ with decision makers). As such, they had lower rates of responding either yes or no compared with Florida decision-maker respondents. In addition, the ratio of this response was also different between the two populations, with a ratio of nearly $1: 4$ for yes/no responses in residents, compared with a ratio of nearly $1: 3$ in decision makers. Research in MinneapolisSaint Paul, MN, found marked differences among suburban, exurban, and urban respondents in their awareness of irrigation and grass height ordinances, with suburban residents having far greater awareness (Sisser et al., 2016). As this research surveyed residents across the state in different residential conditions, further segregation of the data could illuminate populations to target for improving policy awareness. Survey research from the Tampa Bay, FL, area demonstrated that residents in Pinellas County, with Florida's most restrictive fertilizer ordinance, which includes a sales ban, reported the highest level of policy awareness, as well as awareness about not fertilizing before a hard rain or in the summer (Souto et al., 2019). In addition, surveys conducted through HOA email lists in Manatee County, FL, found that $54 \%$ of respondents had not seen any outreach material related to fertilizer blackout periods. Only $32 \%$ of respondents were aware that $\mathrm{N}$ application was banned during the summer months in the county, and even fewer respondents (16\%) were aware that $\mathrm{P}$ application was banned (Persaud et al., 2016). These low rates of policy awareness are similar to the findings in our study, which found that only $31.5 \%$ of Florida resident respondents could accurately identify if they lived in a county/ municipality with a fertilizer blackout period.

Florida decision makers were more likely to correctly identify the blackout policy for their resided city or county in comparison with general Florida residents. They were also less likely to be unsure. These results are somewhat intuitive. The individuals who work directly with policy creation are more likely to be accurately aware of policies. However, research has shown that women are less likely to guess when unsure and are more likely to select "don't know." When the "don't know" prompt is removed, it reduced $50 \%$ of the gender gap in tested political knowledge (Mondak and Anderson, 2004). As decision-maker respondents were more likely to be men (data not shown), and unsure was provided as a prompt, a gender division in how this question was answered may have influenced the lower rates of "unsure" being selected when prompting knowledge on blackout status among Florida decision makers. Future data collection may benefit from removing an "unsure" prompt, especially when contrasting populations with stark differences in gender ratios.

KNOWLEDGE PRODUCTION AND CIVIC SCIENCE. Although both Florida resident respondents and Florida decision-maker respondents were neutral regarding their turfgrass sentiments, it does not negate the discourse aimed at either of these populations espousing both the benefits and detriments of turfgrass. Although turfgrass industry 
organizations, such as the Florida Turfgrass Association and the Turfgrass Producers of Florida, endorse the benefits of having a turfgrass lawn (Florida Turfgrass Association, n.d.; Turfgrass Producers of Florida, n.d.), organizations like the Sierra Club and the Florida Native Plant Society emphasize the negatives to turfgrass and encourage people to plant turfgrass alternatives (Florida Native Plant Society, n.d.; Shmuark, 2016).

Traditionally, environmental policy adoption has been viewed in a dualistic manner between policymakers and scientists. Civic science advocates for a democratic perspective in which citizens participate in the science-politics interface. Scientific knowledge production cannot be viewed as being outside of environmental politics, and civic science can improve civic participation in science, increase diverse demographic representation in scientific knowledge production, and democratize the scientific process. As citizens are not merely recipients of policy, increased focus should be placed on the role of citizens as an intermediary between science and policy (Bäckstrand, 2003). One relevant example of civic science being conducted at UF is the Florida Lakewatch program, which has existed since 1986 (Hoyer et al., 2014). There are more than 1000 volunteer citizen participants who have collected water quality data from more than 1100 lakes, 175 coastal sites, 120 rivers, and five springs, resulting in 36 publications in 12 separate academic journals through 2014 . These citizen-generated data have direct policy implications: the FDEP currently uses Lakewatch program data to evaluate total maximum daily load (Hoyer et al., 2014). Additional research verified the value of these data, with volunteer samplers using Lakewatch protocol generating data of similar quality to professional biologists (Canfield et al., 2002). Potential future turfgrass-related civic science programs could be developed to track mismanagement of landscaping practices by both professionals and homeowners (such as fertilizer on the streets/sidewalks, or grass clippings in the gutters), perhaps with a mobile phone app using global positioning system coordinates, which could even be used jointly with Florida Lakewatch program data to determine connections between lawn management practice on the impairment of water bodies.

\section{Conclusion}

With fertilizer blackout ordinances bringing about claims of scientific corruption in relation to environmental policy advocacy, cultivating a model of civic science may be particularly powerful in redefining the role of the citizen as an interface between science and policy. As a minority of Florida resident respondents are able to accurately identify the fertilizer blackout policy of their city or county (only $32 \%$ could, contrasted with $81 \%$ of Florida decisionmaker respondents), there is evidence for the strong necessity of increased civic engagement in environmental policy adoption. A scientist-policymaker exclusionary interface serves neither the scientists, the policymakers, nor the environment, as citizens ultimately remain ignorant to environmental policy. Researchers and policymakers alike need to emphasize civic participation in the policy adoption process, as this participation leads to high rates of awareness of policy.

This research demonstrates there are differences between Florida residents and decision makers, both in the perceived blackout status of their city or county, but also in the accuracy of this perception. With Florida residents having lower levels of trust in landscape science compared with Florida decision makers, there may be great benefit in increasing civic science participation. Through increasing the role of the average citizen in both knowledge production, as well as policy adoption, it may be possible to simultaneously increase trust in landscape science. Ultimately, a shift in the power dynamics among scientists, residents, and decision makers is necessary to decrease the ongoing controversy and yield ecological solutions that are mutually agreeable.

\section{Literature cited}

Bäckstrand, K. 2003. Civic science for sustainability: Reframing the role of experts, policy-makers and citizens in environmental governance. Glob. Environ. Polit. 3(4):24-41.
Baker, R., J.M. Brick, N.A. Bates, M. Battaglia, M.P. Couper, J.A. Dever, K.J. Gile, and R. Tourangeau. 2013. Summary report of the AAPOR task force on nonprobability sampling. Amer. Assn. Public Opinion Res. 1(2):90-143.

Busey, P., E. Santella, and T. Stone. 2000. Comments on the St. Johns County fertilizer-use ordinance. The Florida Green 2000(Spring):82-86. 10 July 2019. $<$ http://archive.lib.msu.edu/tic/flgre/ article/2000spr82a.pdf>.

Canfield, D.E., C.D. Brown, R.W. Bachmann, and M.V. Hoyer. 2002. Volunteer lake monitoring: Testing the reliability of data collected by the Florida LAKEWATCH program. Lake Reserv. Mgt. 18(1):1-9.

Crabbe, N. 2011. Sierra Club sues UF over public records on fertilizer research. 31 May 2017. <http://www.gainesville. $\mathrm{com} /$ news/20110921/sierra-club-suesuf-over-public-records-on-fertilizerresearch>.

Cohen, J. 1988. Statistical power analysis for the behavioral sciences. 2nd ed. New York Univ., New York, NY.

Cronbach, L.J. 1951. Coefficient alpha and the internal structure of tests. Psychometrika 16(3):297-334.

Dillman, D.A., J.D. Smyth, and L.M. Christian. 2009. Internet, mail, and mixed-mode surveys - The tailored design method. 3rd ed. Wiley, Hoboken, NJ.

Downs, P.E., J. St. Germain, and J. Burnside. 2012. Southwest Florida Water Management District focus groups for northern counties water conservation 10 Jan. 2012 | Final report. 10 July 2019. <https://www.swfwmd.state.fl.us/sites/ default/files/medias/documents/ Northern_Counties_Focus_Group_ Final_Report_Kerr__Downs_1_12_12. pdf $>$.

Downs, P.E. 2007. Southwest Florida Water Management District Crystal River/Kings Bay \& Rainbow River septic system, fertilizer and pesticide use watershed education program focus group report. 10 July 2019. <https://www. swfwmd.state.fl.us/sites/default/files/ medias/documents/.Crystal_RiverKings_ Bay__Rainbow_River_Watershed_ Education_Program_Focus_Group_ Report_0.pdf>.

Environmental Research \& Education Foundation. n.d. About EREF. 31 May 2017. <http://www.ereflorida.com/ about>.

Feagan, R.B. and M. Ripmeester. 1999. Contesting natural(ized) lawns: A geography of private green space in the Niagara region. Urban Geogr. 20(7):617-634. 
Feagan, R. and M. Ripmeester. 2001. Reading private green space: Competing geographic identities at the level of the lawn. Philos. Geogr. 4(1):79-95.

Florida-Friendly Landscaping. n.d.-a. These nine principles will help you reach the goal of a Florida-friendly yard. 28 May 2019 . <https://ffl.ifas.ufl.edu/ homeowners/nine_principles.htm>.

Florida-Friendly Landscaping. n.d.-b. The Florida-friendly landscaping ${ }^{\mathrm{TM}}$ program. 28 May 2019. <https://ffl.ifas.ufl. edu/about.htm>.

Florida-Friendly Landscaping. n.d.-c. GIBMP training \& program overview. 28 May 2019. <https://ffl.ifas.ufl.edu/ professionals/BMP_overview.htm $>$.

Florida Native Plant Society. n.d. Frequently asked questions. 12 Apr. 2017. <http://www.fnps.org/resources/ faqs $>$.

Florida Turfgrass Association. n.d. Florida Turfgrass Association. 12 Apr. 2017. <http://www.ftga.org>.

Florida Yards \& Neighborhood Program. 2006. Florida Yards \& Neighborhoods handbook. A guide to Florida-friendly landscaping. 3rd ed. 29 May 2019. <ht tp://www.floridayards.org/ landscape/FYNHandbook.pdf>.

Foucault, M. 1978 (1990). The history of sexuality. Volume 1: An introduction. (translated from French by R. Hurley). Vintage Books, New York, NY.

Fraser, J.C., J.T. Bazuin, L.E. Band, and J.M. Grove. 2013. Covenants, cohesion, and community: The effects of neighborhood governance on lawn fertilization. Landsc. Urban Plan. 115:30-38.

Gray, S., R. Shwom, and R. Jordan. 2012. Understanding factors that influence stakeholder trust of natural resource science and institutions. Environ. Manage. 49(3):663-674.

Groffman, P.M., J.M. Grove, C. Polsky, N.D. Bettez, J.L. Morse, J. CavenderBares, S.J. Sharon, J.B. Heffernan, S.E. Hobbie, K.L. Larson, C. Neill, K. Nelson, L. Ogden, J. O’Neil-Dunne, D. Pataki, R.R. Chodhury, and D.H. Locke. 2016. Satisfaction, water and fertilizer use in the American residential macrosystem. Environ. Res. Lett. 11(3):1-7.

Helfand, G.E., J. Sik Park, J.I. Nassauer, and S. Kosek. 2006. The economics of native plants in residential landscape designs. Landsc. Urban Plan. 78(3):229-240.

Hochmuth, G., T. Nell, J. Sartain, J.B. Unruh, C. Martinez, L. Trenholm, and J. Cisar. 2009. Urban water quality and fertilizer ordinances: Avoiding unintended consequences: A review of the scientific literatures. Univ. Florida Inst. Food Agr. Sci. Publ. SL 283. 23 Jan. 2019. <http://edis.ifas.ufl.edu/ss496>.

Hochmuth, G., T. Nell, J.B. Unruh, L. Trenholm, and J. Sartain. 2012. Potential unintended consequences associated with urban fertilizer bans in Florida - A scientific review. HortTechnology 22:600616.

Hoffer, S. 2011. Oak Park, Michigan resident Julie Bass faces 93 days in jail for vegetable garden. 31 May 2017. <http:// www.huffingtonpost.com/2011/07/ 08/julie-bass-jail-vegetablegarden_n_ 893436.html>.

Hoyer, M.V., D.L. Bigham, R.W. Bachmann, and D.E. Canfield, Jr. 2014. Florida LAKEWATCH: Citizen scientists protecting Florida's aquatic systems. Fla. Sci. 77(4):184.

Johns, R.A. 2008. Ecologically appropriate residential landscaping in Pinellas County, Florida: Barriers and incentives. Papers Appl. Geography Conf. 31:283291.

Kalton, G. and I. Flores-Cervantes. 2003. Weighting methods. J. Off. Stat. 19(2):81-97.

Krishnaswami, R.J. and E. Merton. 2015. Neglected yards and community landscaping. Southeast. Geogr. 55(2):225251.

Lamm, A.J. 2013. Public opinions of water in Florida. Univ. Florida Inst. Food Agr. Sci. Ctr. Public Issues Educ. PIE2012/13-06B1. 10 July 2019. <http://www.piecenter.com/wpcontent/uploads/2015/09/ WaterPanelReportFINAL_Yrl.pdf>.

Law, N., L. Band, and M. Grove. 2004. Nitrogen input from residential lawn care practices in suburban watersheds in Baltimore County, MD. J. Environ. Plann. Mgt. 47(5):737-755.

Martin, C.A., K.A. Peterson, and L.B. Stabler. 2003. Residential landscaping in Phoenix, Arizona, US: Practices and preferences relative to covenants, codes, and restrictions. J. Arboric. 29(1):9-17.

Martini, N.F., K.C. Nelson, S.E. Hobbie, and L.A. Baker. 2015. Why "feed the lawn"? Exploring the influences on residential turf grass fertilization in the Minneapolis- Saint Paul metropolitan area. Environ. Behav. 47(2):158-183.

Mondak, J.J. and M.R. Anderson. 2004. The knowledge gap: A reexamination of gender-based differences in political knowledge. J. Polit. 66(2):492-512.

Mustafa, D., T.A. Smucker, F. Ginn, R. Johns, and S. Connely. 2010. Xeriscape people and the cultural politics of turf- grass transformation. Environ. Plann. D Soc. Space 28(4):600-617.

Nassauer, J.I. 1995. Messy ecosystems, orderly frames. Landscape J. 14(2):161170.

National Science Board. 2014. Science and technology: Public attitudes and understanding. 10 July 2019. <https:// www.nsf.gov/statistics / seind 14/ content/chapter-7/chapter-7.pdf>.

Ovalle, D. 2016. Plastic flamingos are $\mathrm{OK}$, but veggie garden is not: A frontyard legal battle. 31 May 2017. <http:// www.miamiherald.com/news/local/ community/miami-dade/miami-shores/ article82553982.html>.

Persaud, A., K. Alsharif, P. Monaghan, F. Akiwumi, M.C. Morera, and E. Ott. 2016. Landscaping practices, community perceptions, and social indicators for stormwater nonpoint source pollution management. Sustainable Cities Soc. 27:377-385.

Ryan, C.D. 2016. Florida lawn and landscape fertilizer restrictions - A survey of residents and decision makers. Univ. Florida, Gainesville, MS Thesis.

Sharp, L. and T. Richardson. 2001. Reflections on Foucauldian discourse analysis in planning and environmental policy research. J. Environ. Policy Plann. 3(3):193-210.

Shmuark, S. 2016. How to put your yard to work for the climate. 31 May 2017. <http://www.sierraclub.org/sierra/ 2016-4-july-august/green-life/howput-your-yard-work-for-climate $>$.

Sierra Club Florida. 2019. Inside the Florida chapter. 28 May 2019. <https:// www.sierraclub.org/florida/insideflorida-chapter $>$.

Sisser, J.M., K.C. Nelson, K.L. Larson, L.A. Ogden, C. Polsky, and R.R. Chowdhury. 2016. Lawn enforcement: How municipal policies and neighborhood norms influence homeowner residential landscape management. Landsc. Urban Plan. 150:16-25.

Souto, L. and B. Marshall. 2007. Southwest Florida Water Management District outdoor water use focus group research August - September 2007 final report. PO\#0001262. 10 July 2019. <https:// www.swfwmd.state.fl.us/sites/default/ files/medias/documents/Outdoor_ Water_Use_Irrigation_Pilot_Program_ Focus_Groups_Report.pdf $>$.

Souto, L., C.M.C.S. Listopad, and P.J. Bohlen. 2019. Forging linkages between social drivers and ecological processes in the residential landscape. Landsc. Urban Plan. 185:96-106. 
St. Hilaire, R., D.M. VanLeeuwen, and P. Torres. 2010. Landscape preferences and water conservation choices of residents in a high desert environment. HortTechnology 20:308-314.

Sturgis, P. and N. Allum. 2004. Science in society: Re-evaluating the deficit model of public attitudes. Public Underst. Sci. 13(1):55-74.

Tampa Bay Times. 2012. Meddling with fertilizer. 29 May 2019. <https://web. archive.org/web/20130417055140/ http://www.tbo.com/list/newsopinion-editorials/meddling-withfertilizer-352569/>.

Taylor, M. and A.J. Lamm. 2016. Minimizing disparities and developing support by identifying differences in confidence and knowledge related to water issues. J. Ext. 54(6):6FEA6. 10 July 2019. <https://www.joe.org/joe/ 2016december/a6.php>.

Turfgrass Producers of Florida. n.d. Environmental benefits - turfgrass is good for the environment. 12 Apr. 2017. $<$ http://floridaturf.com/homeowners/ environmental-benefits/ $>$.

Valtin, T. 2012. Club helps preserve strong Florida fertilizer regs. 23 Jan. 2019. <http://blogs.sierraclub.org/ scrapbook/2012/02/club-helpspreserve-strong-florida-fertilizer-regs. html>.

WESH Orlando. 2013. Group blames fertilizer for manatee deaths. 31 May 2017. <http://www.wesh.com/news/ central-florida/brevard-county/groupblames-fertilizer-for-manatee-deaths/ 19975608>. 